\title{
Role of the WTO in the Development of International Trade and Economic Sustainability
}

\author{
Ph.D. candidate Giga Abuseridze \\ ORCID: 0000-0003-2868-8719 \\ Rìga Stradiňš University, Faculty of Law, Latvia \\ giga.abuseridze@rsu.lv
}

\begin{abstract}
In the article, the role of the World Trade Organisation (WTO) in the development of international trade and economic sustainability has been analysed. The author explores specific challenges / factors that affect economic sustainability and fair trade as well as political economy of trade and negotiations as the tools of the WTO. It is argued that economic stability and the process of democratisation are essential to ensure international and fair trade. Under democracies those countries are implied where the rate of economic stability is high according to the principles established by international norms, i.e. where market economy, internal democracy, transparent trade system, human rights, trade neutrality, etc. are observed. Almost every country where these democratic norms are applied has trade partnerships with the others rather than conflicts. For international trade to occur it is essential to have a competitive market system in a country since competition is a characteristic feature of international trade that can be safeguarded through observation of democratic principles and political stability. Development of free trade by the WTO depends precisely on implementation of these fundamental principles. In view of the abovementioned factors, the article quite legitimately studies interconnection between the WTO and economic sustainability.

Keywords: Agreement on Trade-Related Aspects of Intellectual Property Rights, dispute settlement understanding, general agreements on tariffs and trade, regional trade agreements, World Trade Organisation.
\end{abstract}

\section{Introduction}

In the current highly interlinked and globalised world, it is essential for each country to ensure trade, economic and political stability so that both local communities and communities living in the neighbouring countries could feel safe. Against 
the backdrop of globalisation, the World Trade Organisation (WTO) plays an important role in ensuring trade stability, economic sustainability, and fair trade. WTO's rules stabilize the world economy by discouraging sharp backward steps in economic policy and by making trade policy more predictable. Trade stability is ensured not only by adequate policies and reforms in the political or social sphere, equally important is the economic sphere with such factors as unemployment, fiscal policy, growth in incomes and inflation. Effective economic development, trade and political stability as the main aims of the WTO can be achieved only if the WTO politicians thoroughly consider factors hindering the development of each WTO member state in terms of legislation, security policy, welfare, economic situation.

The author poses a number of questions about the WTO: What is the role of the WTO Basic Rules in the development of international trade? What challenges and threats is the WTO today facing? Can we assume that the main reason for the success of the WTO lies in its regulation?

To answer such questions, the author will analyse legal, political and economic framework of the WTO, in which the states began to cooperate to create an international mechanism for promoting sustainable world trade / economy.

\section{Rules of WTO for International Trade and Current Challenges}

Establishment of the WTO at Uruguay Round was aimed at creating an integrated legal system in world trade relations for free and fair trade. Today, many critics of the WTO claim that the WTO is "pathologically secretive, conspiratorial and unaccountable to sovereign states and their electorate" (Jonquieres, 1999). Developing country members criticise the WTO and object to what they consider to be their marginalisation within the WTO's negotiation and rule-making process. While for many years international trade law was not part of the mainstream of international law, the WTO law is now the "new frontier" of international law. Nobody questions that the WTO law is an integral part of public international law.

Globalisation and international trade need to be properly managed if they are to be of benefit to all humankind. In 1997, former GATT and WTO director-general, Peter Sutherland, wrote: "The greatest challenge facing the world is the need to create an international system that not only maximises global growth but also achieves a greater measure of equity, a system that both integrates emerging powers and assists currently marginalised countries in their efforts to participate in worldwide economic expansion. The most important means available to secure peace and prosperity into the future is to develop effective multilateral approaches and institutions" (Sutherland, 1997).

Yet, the questions remain what exactly the role of legal rules and, in particular, international legal rules in international trade is; how international trade rules allow countries to realise the gains of international trade. There are four related reasons why 
Giga Abuseridze. Role of the WTO in the Development of

International Trade and Economic Sustainability

there is a need for international trade rules. First, countries must be restrained from adopting trade-restrictive measures both in their own interest and in that of the world economy. International trade rules restrain countries from taking trade-restrictive measures. National policy-makers may come under considerable pressure from influential interest groups to adopt trade-restrictive measures in order to protect domestic industries from import competition. Such measures may benefit the specific, shortterm interests of the groups advocating them, but they very seldom benefit the general economic interest of the country adopting them. "Governments know very well that by tying their hands to the mast, reciprocal international pre-commitments help them to resist the siren-like temptations from rent-seeking, interest groups at home" (Bossche \& Zdouc, 2013).

Countries also realise that if they take trade-restrictive measures, other countries will do so too. This may lead to escalation of trade-restrictive measures, a disastrous move for international trade and global economic welfare. International trade rules help to avoid such escalation. A closely related reason why international trade rules are necessary is the need of traders and investors for a degree of security and predictability. International trade rules offer such degree of security and predictability. Traders and investors operating or intending to operate in a country that is bound by such legal rules will be able to predict better how that country will act in the future on matters affecting their operations in that country. Another reason is that national governments alone cannot cope with the challenges presented by globalisation. International trade rules serve to ensure that countries only maintain national regulatory measures that are necessary for protection of the above key societal values (Jackson, 1998). Furthermore, international trade rules may introduce a degree of harmonisation of domestic regulatory measures and thus ensure an effective, international protection of these societal values. Moreover, international trade rules are necessary to achieve a greater measure of equity in international economic relations. Without international trade rules, binding and enforceable on the rich as well as the poor, and rules recognising the special needs of developing countries, many of these countries would not be able to integrate fully in the world trading system and derive an equitable share of the gains of international trade (Abuseridze, 2021).

The author claims that nowadays' challenges to the WTO against the background of globalisation make the trading platform unstable. One of the clear examples of trade instability is caused by the Covid-19 pandemic. In the early stage of pandemic, the countries shut down their borders and introduced export restrictions on medical equipment and supplies. Restriction of export which is against WTO rules, occurs only in exceptional circumstances and for limited time. Under current pandemic, demand on some goods and essential supplies increased dramatically, causing supply distortions. Lockdowns and disruption in transportation also caused economic decline. Some countries started to apply protective measures and widely use stimulus packages and subsidies. All these measures are trade distortive measures and create vulnerability for WTO system. In the present 
Giga Abuseridze. Role of the WTO in the Development of

International Trade and Economic Sustainability

circumstances, it is crucial to return to normality soon to avoid additional difficulties and further damage of multilateral trading system (WTO, 2020).

The author also argues that the biggest threat to the global trade is trade wars that would do serious damage to global economy as protectionist actions escalate. Countries imposing tariffs and countries subject to tariffs would experience losses in economic welfare, while countries on sidelines would experience collateral damage. In order to avoid such scenarios, WTO has dispute settlement mechanism and countries have a possibility to apply it for resolution of their dispute (recently even this mechanism was challenged, thus hindering trade dispute settlements in fair manner). According to the author, following the numbers, it can be observed that every year a growing number of countries is applying for dispute settlement.

In the author's view, the most evident challenge is the Doha Development Round, the current round of multilateral trade negotiations to further liberalise trade and reform the WTO. After a decade of talks, discussions remain at a standstill. The Doha Round is focused on reducing critical trade barriers in areas such as agriculture, industrial goods, and services. This would urge businesses around the world to specialise in production of goods and services, achieve greater economic status, and increase their efficiency and productivity, all of which would permit them to deliver higher quality and cheaper products to international consumers. With the various challenges that lie ahead, new thinking is needed in the WTO. The approaches of twenty years ago are no longer adequate to today's global obstacles. The WTO Secretariat needs to begin a process that will revitalise the organisation and equip it to deal with the changing international economic environment. Regarding the future of the WTO, it has a great opportunity to improve sovereignty, democracy and the market. All three ideas have nonetheless come down to as foundations of modern international society, and to which all members of that society are at least rhetorically devoted. Two of the three concepts are indispensable to multilateral trading system: there could be no WTO without sovereignty and international law, and it would have no purpose without market economics. WTO should be oriented in the future on democracy between members: leadership and burden-sharing, the future of the multilateral trading system depends in part on the ability of negotiators and political leaders to demonstrate the value of trade liberalisation to legislators and representatives of civil society. The author argues that the WTO should focus on Institutional reforms. At issue are the changes members might make in the WTO as an institution, how they might make better use of the information that the system generates, and what new ideas may develop for the trading system.

According to the author, the future of the organisation is determined through identifying existing problems and assessing the challenges in the context of globalisation. However, the latest trade tension has put the WTO's Dispute Settlement function, long referred to as the "jewel" of the WTO under question. Therefore, to ensure credibility of the WTO and its effective work, the author takes the initiative to start procedural actions to eliminate this problem. The author claims that despite some successes in 
the first 25 years in terms of negotiated improvements, the WTO's set of agreements are largely reflective of the world in the 1980s. Advances in technology, manufacturing make-up and importance of certain service sectors (e.g., e-commerce, human rights) are not covered by the existing agreements. Therefore, this issue should be considered when talking about the future of the organisation.

Regarding WTO regulations, the author believes that the WTO plays an important role in political and trade stabilisation by setting regulations for all WTO Member States which they need to comply with to integrate with the organisation and effectively collaborate with other WTO Member States. They will coexist with other member countries which share the unified system of values. Hence, sharing of the common values by the member countries, transparent trade rules and dispute settlement mechanism adds to the organisation's stability.

\section{Political Economy of Trade and Negotiations as the Tool of the WTO}

In the $21^{\text {st }}$ century, international trade is considered as a multidisciplinary field. Fundamental and systemic analysis clearly demonstrates that international trade regulates trade rules but inherently bears both economic and political content. Any trade war, for example US-China trade war, or trade disputes bear political connotation i.e., a political decision should regulate trade relations. When damage is inflicted, it is already a fact of economic value. Therefore, the author argues that in international trade law economics and politics cohabitate.

Free trade increases wealth and reduces poverty, and, thus, it may contribute to social stability through economics of comparative advantage (Bagwell \& Petros, 2011). Both the WTO and World Bank suggest that trade liberalisation is a positive contributor to social stability (Nordström \& Winters, 1999).

Trade growth and political stability are deeply interconnected. On the one hand, uncertainty associated with an unstable political environment may reduce investment and pace of economic development (Bartels \& Ortino, 2006). On the other hand, poor trade and economic performance may lead to government collapse and political unrest (Dollar \& Kraay, 2002). However, political stability can be achieved through oppression or through having a political party in place that does not have to compete to be re-elected. In such cases, political stability can have its favourable and unfavourable consequences. While the peaceful environment that political stability may offer is a desideratum, it could easily become a breeding ground for cronyism with impunity. Such is the dilemma that many countries with a fragile political order have to face (De-Ville \& Brügge, 2015).

Democracy and political stability provide conditions for promoting free trade, which in its turn may increase wealth and reduce poverty, and, thus, it may contribute to social stability through the economics of comparative advantage (Abuseridze, 2020). 
Giga Abuseridze. Role of the WTO in the Development of

International Trade and Economic Sustainability

It is important to note that domestic politics shape countries' strategic decisions to negotiate regional trade agreements (RTAs) and are even more important in determining at the tactical level the kinds of commitments countries seek or grant in these agreements.

To simplify, political scientists who look to domestic political factors in order to explain the countries' choices between openness and closure tend to fall into three general camps. The oldest and perhaps largest school of thought depicts this choice as the outcome of struggles between competing economic interests. Openness represents the triumph of pro-trade interests such as exporters, retailers, and consumers over importcompeting industries, labour unions, or others that are typically trade-sceptical. A second category of explanations shifts the locus of conflict from civil society to government, and sees openness as the triumph of pro-trade institutions (e.g. the executive branch in general, the foreign ministry, etc.) over their trade-sceptical rivals (e.g. legislatures or client-oriented ministries). Yet a third approach pays more attention to ideas than to interests. Analysts in this school argue that openness represents victory of liberal ideology over protectionist doctrines. While the debates among the proponents of these three schools of thought are sometimes conducted as if the explanations were mutually exclusive, it is possible that each captures some part of truth. In any given country, the decision to open the market may be influenced by a mixture of sectoral, institutional, and ideological factors.

Regarding negotiations, an important role of the WTO is to house negotiations on trade liberalisation. The author argues that negotiations are inevitably a reflection of different interests of different countries and country groups. On majority of issues, decisions are made by consensus in the WTO, which means that countries should find necessary balance between different interests. The world at the time of the Uruguay Round was different from today's. This is clearly shown on the duration of negotiation rounds in the WTO. The last round of negotiations - "Doha round" was launched in Doha in 2001 and it is still ongoing, the author has described this in detail above (WTO, 2020). Developing countries currently have much more clout than the negotiating agenda and the negotiations themselves demonstrate. Also, the WTO system gives the possibility to defend their trading interests. The TRIPS has been agreed by developing countries, which also protects them (Palkova \& Abuseridze, 2020).

In the modern circumstances, negotiations are based on the principles established by international norms, i.e., where free trade, specific market access commitments etc. are observed. The talks can be highly complicated. In some cases, negotiations are almost as large as an entire round of multilateral trade negotiations. For example, when negotiations are underway for membership in the organisation, the new member's commitments are to apply equally to all WTO members under normal non-discrimination rules, even though they are negotiated bilaterally.

The author attaches special importance to the role of the WTO in the process of trade stability. He argues that the role of the WTO as the umpire in trade disputes has 
been greatly threatened by the US-China trade war. With the burst of the US-China trade war, it has been observed that there is an urgent need for DSU reform. The author believes that although this would increase trust of the member states in dispute settlement system, it may not be the only solution for preventing trade wars. With the global tension brought about by the trade war between the US and China, there is perfect timing for reforms in the WTO to strengthen the multilateral trading system (WTO, 2021). In the long run, the author views the WTO as an active party in ensuring a successful round of negotiations to address existing challenges. Ultimately, it can be stated that the trade war affected not only the two countries, but also the global economic picture. Global trade was hit $2.5 \%$ by the game of tariff barriers between the US and China amid the trade war, according to a 2019 World Bank report. The main economic threat according to the report was the trade dispute between the United States and China (The World Bank, 2019). The author believes that countries should reconsider their economic policies and choose to protect their own market, rather than intervene in global trade processes.

\section{Conclusion}

The author has concluded that the WTO, by virtue of its competence, is undoubtedly one of the key organisations that regulate international trade and economic relations almost all over the world. It is also a crucial legislative body in modern international relations, which, despite widespread criticism, is an exemplary successful international organisation.

According to the author, the WTO plays an important role for the intergovernmental community, given its substantial jurisdiction and existence of an effective mechanism for multilateral international agreements concluded within its framework. Its importance in modern international relations is especially evident in view of the list of areas covered by this organisation, including intellectual property, environmental protection, technical barriers to trade, investment mechanisms and other important aspects. One of the reasons for the success of the WTO, in the author's opinion is the effective implementation mechanism of international agreements between the member states, the unimpeded functioning of which has been guaranteed by the Dispute Settlement Mechanism established at Uruguay Round. Its effectiveness is confirmed by interstate disputes in the WTO, the sentences of which are always distinguished by an effective enforcement mechanism. An exception is the recent escalation of trade tensions between the United States and China, of which the author is critical. However, the author argues that the WTO maintains a balance of power since small member states can express their views on the development of world trade, using all mechanisms to protect their interests. These facts allow to conclude that the organisation greatly contributes to interpretation and development of international trade and economic sustainability. 
Giga Abuseridze. Role of the WTO in the Development of International Trade and Economic Sustainability

\section{Bibliography}

1. Abuseridze, G. (2021). International Trade in the Context of the COVID-19 Pandemic. Impact of Infodemic on Organizational Performance. DOI:10.4018/978-1-7998-7164-4.ch013.

2. Abuseridze, G. (2020). Political Stability and Trade Agreements. Bulletin of the Georgian National Academy of Science. 14(4), 139-140.

3. Bagwell K. W. \& Petros C. (2011). Mavroidis Preferential Trade Agreements: A Law and Economics Analysis. Cambridge: Cambridge University Press.

4. Bartels, L., \& Ortino, F. (Eds.) (2006). Regional Trade Agreements and the WTO Legal System. Oxford Univ. Press. DOI:10.1093/acprof:oso/9780199206995.001.0001

5. Ben-David, D. Nordström, H., \& Winters A. (1999). Trade, Income Disparity and Poverty. WTO Publications. https://www.wto.org/english/news_e/pres00_e/pov1_e.pdf

6. Bossche, P., \& Zdouc W. (2013). The Law and Policy of the World Trade Organization. Cambridge: Cambridge University Press.

7. De-Ville, F., \& Brügge G. (2015). The Transatlantic Trade and Investment Partnership and the Role of Computable General Equilibrium Modeling: An Exercise in 'Managing Fictional Expectations. New Political Economy, 5, 653-678.

8. Dollar, D., \& Kraay, A. (2002). Growth Is Good for the Poor. Journal of Economic Growth, 7, 195-225.

9. Jackson, J. (1998). Global Economic and International Economic Law. Journal of International Economic Law, 1(1), 1-24. https://doi.org/10.1093/jiel/1.1.1

10. Jonquieres, G. (1999). Prime Target for Protests: WTO Ministerial Conference. Financial Times, 24.09.1999.

11. Palkova, K., \& Abuseridze, G. (2020). Human Rights and Labour Standards from the Public Health Perspective in the World Trade Organization: Challenges and Possible Solutions. Journal of Economics Studies and Research, 2020. https://doi.org/10.5171/2020.423674

12. Sutherland, P. (1997). Beyond the Market, a Different Kind of Equity. The New York Times, 20.02.1997.

13. World Bank. (2019). The World Bank Annual Report 2019: Ending Poverty, Investing in Opportunity. https://documents.worldbank.org/en/publication/documents-reports/documentdetail/156691570147766895/the-world-bank-annual-report-2019-ending-poverty-investingin-opportunity

14. World Trade Organization. (2020). Annual Report. https://www.wto.org/english/res_e/booksp_e/ anrep_e/anrep20_chap1_e.pdf

15. World Trade Organization. (2021). Panel issues report regarding US tariffs on Chinese goods. https://www.wto.org/english/tratop_e/dispu_e/543r_conc_e.pdf

16. World Trade Organization. (2020). Trade set to plunge as COVID-19 pandemic upends global economy. https://www.wto.org/english/news_e/pres20_e/pr855_e.htm 